\title{
Crisis Communication of President of Ukraine Volodymyr Zelenskyi on Counteracting COVID-19: Sociolinguistic Features
}

\author{
Liudmyla Bilokonenko ${ }^{1, *}$ \\ ${ }^{I}$ Kryvyi Rih State Pedagogical University, Ukraine \\ "Corresponding author. Email: bk.ludmila1020@gmail.com
}

\begin{abstract}
The paper examines the discursive and linguistic means of appeals of the Ukrainian President V. Zelenskyi in 2020 to citizens on the spread of the COVID-19 pandemic. Our analysis results suggest that in Ukraine, the rhetoric of the President's appeals demonstrates the spread of nationally oriented power mechanisms of discourse, which depend on the social context more than in highly developed countries. We compare the organization of V. Zelenskyi's statements about COVID-19, which are addressed to ordinary citizens and government officials. We conclude that the President appeals most to national values and symbols, transforming them into a radical national hope.
\end{abstract}

Keywords: socio-cognitive approach, political language, analysis of socio-political discourse, pandemic COVID-19.

\section{1. ВСТУП}

Актуальність і мета дослідження. Публічні виступи Президента - сфера високої комунікативної відповідальності, оскільки це офіційне спілкування глави держави 3 громадянами. Тому засоби мовного впливу вирізняються від тих, якими послуговуються в інших стилях мови. Політична мова призначена для політичної комунікації, знаходження суспільної позиції, аргументації намірів, пояснення завдань.

Критичний аналіз дискурсу виступів політиків в останні десятиліття цікавить дослідників усе більше [1; 2]. Вони зазначають, що в політичній мові завжди фіксується специфічна експресивність, метафоризація, спонукальність, оцінність; професійний політик оперує символами, “театралізуючи” свій дискурс [3; 4; 5; 6]. Проте риторика звернень Президента до українців у 2020 р. щодо протидії COVID-19 дещо трансформується, оскільки з'являються механізми, які актуально сприймати через призму кризової комунікації. Науковці вже зацікавилися дискурсивними та лінгвістичними засобами репрезентації пандемії COVID-19 як макроподії, що стала основою національних мікроподій $[7 ; 8$; 9]; говорять про роль публічних виступів політичного лідера задля практичних наслідків для нього [10].

Мета дослідження: аналіз дискурсивних та лінгвістичних засобів, які стали основою кризового спілкування В. Зеленського у 2020 р. 3 громадянами, політичною реакцією на пандемію COVID-19 в Україні та легітимізували політичні дії влади.

\section{2. МЕТОДИ ДОСЛІДЖЕННЯ}

Наше дослідження базуємо на засадах соціально-когнітивного підходу до політичного дискурсу, грунтуємо на основних поняттях теорії аргументації, ураховуємо соціальний аспект національної дискурсивної практики. Наша праця враховує такі аспекти кризового спілкування В. Зеленського: 1) Президент говорить про політичні рішення, які забезпечують існування нації та спрямовує свої зусилля на пояснення ситуації; 2) Президент акцентує на діях органів влади України, які задовольняють функціонування держави задля запобігання COVID. Ми керуємося засадами дискурсивного підходу до політичної 
комунікації Т. ван Дейка, розглядаючи політичний дискурс як текст і розмову професійних політиків або політичних інститутів на міжнародному чи національному рівнях [11]; а також моделлю Н. Фейрклафа [12], звертаючись до соціального контексту виступів, лінгвістичного та семіотичного аналізу текстової побудови.

\section{3. ОПИС ТА ОБГОВОРЕННЯ}

У 2020 p. В. Зеленський виголосив 38 офіційних промов, які оприлюднено на вебсайті Офіційного інтернет-представництва Президента [13]. 3 них у 19 було порушене питання коронавірусу та карантину в Україні. Перше звернення щодо протидії коронавірусу в Україні датоване 13 березня 2020 p. За три місяці Президент багаторазово публічно говорив про пандемію у світі та Україні, адже 30 січня 2020 р. BOO3 оголосила, що спалах COVID-19 - це надзвичайна ситуація у сфері громадського здоров'я міжнародного масштабу. 11 березня 2020 р. Генеральний директор ВООЗ назвав розвиток цієї вірусної хвороби пандемією [14]. I $\begin{array}{llll}\text { вже за два дні по тому } & \text { В. Зеленський }\end{array}$ висловлюється про ризики розповсюдження COVID-19 в Україні.

Усі звернення Президента мають одну тему протидія коронавірусу в Україні. Ця тема розгортається у площинах різних соціальних завдань. За 3 місяці в кожному виступі Президента було озвучено від 15 до 4 соціальних завдань. Інформацію про кількість соціальних завдань у кожному з виступів Президента за період із 13 березня 2020 року по 13 травня 2020 року узагальнимо в рисунку 1.

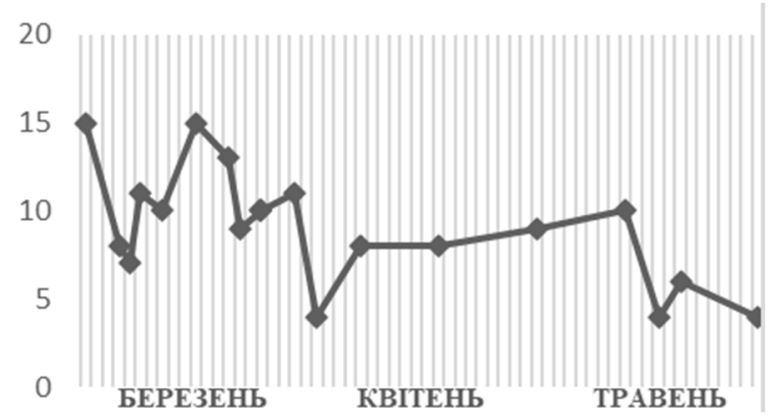

Рисунок 1 Кількість соціальних завдань, названих у промовах Президента щодо COVID-19

Є 5 основних соціальних завдань, порушених у 19 виступах Президента щодо COVID-19: вразливі групи населення та захист здоров'я і життя, робота лікарів і медичне забезпечення, відповідальність державних органів влади, гуманітарна допомога, економіка. До основних соціальних завдань (підтем виступів В. Зеленського) зараховуємо ті, що $є$ найбільш частотними, їх подаємо в таблиці 1. Ці завдання повинні були забезпечити функціонування України в умовах, які стали новим складним викликом для країни.

Таблиця 1. Основні соціальні завдання та їх відтворення у промовах Президента

\begin{tabular}{|c|l|c|}
\hline$№$ & \multicolumn{1}{|c|}{ Соціальні завдання } & $\begin{array}{c}\text { Кількість } \\
\text { відтворень }\end{array}$ \\
\hline 12 & $\begin{array}{l}\text { Вразливі групи населення та } \\
\text { захист здоров'я і життя }\end{array}$ & 19 \\
\hline 2 & $\begin{array}{l}\text { Робота лікарів і медичне } \\
\text { забезпечення }\end{array}$ & 10 \\
\hline 3 & $\begin{array}{l}\text { Відповідальність державних } \\
\text { органів влади }\end{array}$ & 9 \\
\hline 4 & Гуманітарна допомога & 9 \\
\hline 5 & Економіка & 8 \\
\hline
\end{tabular}

\section{1. Соціальне завдання "Вразливі групи населення та захист здоров'я і життя"}

Воно звучить у кожному виступі, зосереджує увагу на особливих концептах, виявляє специфічну метафоричну систему. По-перше, підтема вводиться формами вітання, побажання та прощання. Початково у виступах звучить доволі офіційне звертання Дорогі украӥниі!, формальність якого визнає і Президент: 17 березня він говорить: Усім привіт! Почну не з офіційного “Доброго вечора, дорогі украӥниі", а із забутого, проте дуже актуального сьогодні - “Здоровенькі були” [тут і далі цит. за: 13]. Вітання-побажання Здоровенькі були! відоме завдяки знаному українському акторові Ю. Тимошенку. Молодь не пам'ятає виступи дуету “Тарапунька і Штепсель”, де актор це вітання і вживав. Але посилання про “здоров'я”, реалізоване цією формулою, розраховане на сприйняття людьми старшого віку, тому воно $є$ результативним. У наступному зверненні цей вислів повторений, проте в реченні поєднано дві часові форми дієслів бути - минулий і майбутній (Здоровенькі були, дорогі украӥнці! Були й обов'язково будемо!), ніби підкреслюючи: ми були, $\epsilon$ б будемо, і ми повинні берегти себе. Як доповнення звучить одне 3 речень 20 березня (Сьогодні ми не маємо права думати тільки про власні потреби. I не можемо допустити, щзоб мільйон украӥнців захворіли одночасно).

Президент хоче мати міцний психологічний контакт 3 аудиторією, тому під час виступів активно використовує не тільки мовні, а й позамовні засоби. Він звертається до розуму 
людей за допомогою емоційних слів та поєднує їх iз контрольованими емоційними “сигналами” на обличчі, доречність застосування яких дає змогу просувати власні політичні переваги. Такий дружній емоційний “сигнал” ми бачимо під час вітання (рис. 2).

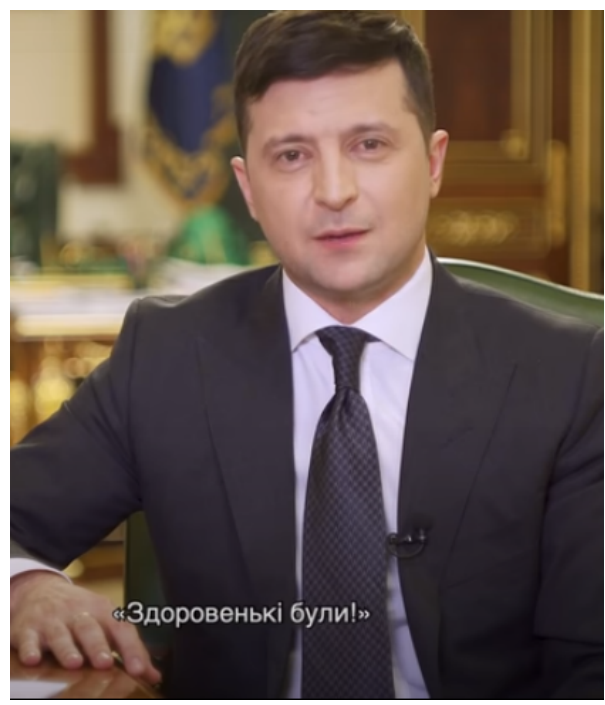

Рисунок 2. Дружній емоційний “сигнал” Президента під час вітання

У виступі 20 березня відчувається офіційність й у викладі думок, і у вітальній формулі (Бажаю здоров'я, дорогі громадяни!). Президент вдається до раціонального накопичення системи знань про роботу держави для виконання свої обов'язків перед громадянами (про експрес-тести, апарати ШВЛ, маски підвищеного захисту для лікарів, роботу голів ОДА і мерів, перемовини з Прем'єрміністром Канади Джастіном Трюдо й офіційними особами з Угорщини та Польщі, повернення українців із-за кордону), однак питання про “здоров'я і життя” залишається ключовим. У подальших зверненнях В. Зеленський віддає перевагу одній стандартній формулі (Бажаю здоров'я, дорогі українці!), яка стає універсальним i традиційним поєднанням звертання Дорогі украӥнці! та побажанням здоров'я (лише один раз вона трансформується (Дорогі украӥнці! Традичійно на початку звернення я бажаю вам здоров'я). Звернімо увагу на дієслово бажаю, форма I особи однини якого сприяє наближенню Президента до українців: він говорить від себе особисто, ніби перебирає на свої плечі складність соціальних проблем.

По-друге, підтема реалізована у фінальних фразах, які комбінують побажання (некатегоричні директиви) та прощання. Вони скомпоновані в окремий блок речень та не вирізняються різноманітністю. Початкова формула Бажаю здоров'я, дорогі українці дещо трансформується (Будьте здорові, дорогі украӥниі або Залишайтеся вдома $і$ будьте здорові, дорогі украӥниі), чим забезпечує обіг ключової думки всього тексту. Наказовий спосіб дієслова залишайтеся сприймається лише як фіксація позиції дружності на стадії завершення спілкування. Повторюваним є побажання Бажаю вам 36,6; 36,6 вам, дорогі україні; Бажаю нам усім 36,6; Бажаю вам всім 36,6. Ми впевнені, що оптимальна температура тіла людини становить $36,6^{\circ} \mathrm{C}$, а відхилення свідчить про розвиток захворювання. I хоча науковці говорять про неточність цих даних, українці сприйняли формулу як еквівалент побажання здоров'я. Останні речення кожного виступу (Бережімо себе! Збережемо Украӥну!) містять дієслова в наказовому способі бережімо та майбутнього часу збережемо. Проте наказ у формі I особи множини визнається як форма побажання для всіх і заклик думати про майбутнє всієї держави: Президент поєднує емоційний i раціональний аспекти своїх звернень.

Тези Президента щодо захисту вразливих груп населення реалізовані простими комунікативними утвореннями, що мають різну структуру і способи вираження. 3 конститутивних ознак повторюваними $\epsilon$ адресант i його мотивація, адресати й тема. В. Зеленському доводиться враховувати інтенсивність вияву трьох ознак кризової комунікації: складність ситуації у країні, ступінь знайомства громадян із COVID-19 та мотивація дій людей. Особливістю введення цього соціального завдання є те, що висловлені поради не містять базових компонентів: адресати не зверталися до Президента з проханням про поради (це пояснюється новизною ситуаціі) та відсутня реакція на неї від адресатів (просторові перешкоди).

Оскільки поради часто стосувалися медичного питання, то специфіка цих висловлень полягає у вибірковості їх різновидів. Українці почули пораду-рекомендацію (Наполегливо рекомендую всім людям залишатися вдома), інструкцію (Допомагають прості речі: мити руки з милом. Ретельно $і$ більше 30 секунд. Користуватися дезінфектором, вітатися, не тиснучи руки та не цілуючи у щуоки один одного, тримати дистанцію в один метр; Обов'язково мийте руки з милом не менше 30 секунд та обробляйте засобами на основі спирту), заклик (Знову хочу закликати всіх без зайвої потреби не виходити на вулицю й залишатися вдома), побажання (Продовжуємо 
зберігати спокій $і$ холодну голову; Продовжуємо залитатися вдома!).

За тональністю прозвучали дружні, але прямолінійні поради, це засвідчують обрані мовні засоби. Подані спонукальні конструкції репрезентовано у ввічливій формі, для чого використано лише кілька імперативних дієслів (мийте, обробляйте), а головно інфінітивні форми (залишатися, мити, користуватися, тримати, не виходити, зберігати). Такі заяви забезпечують пом'якшення наказовості. Дієслова мають правосторонне (Наполегливо рекомендую всім людям залишатися вдома) та лівостороннє (Продовжуємо зберігати спокій $і$ холодну голову) поширення, відповідаючи характерові ситуації, але правосторонніх зафіксовано більше (пояснення передує заклику). Адресант підкреслює, що він особисто дбає про громадян та орієнтований на їхні інтереси, тому застосовує займенник I особи однини та координоване з ним дієслово (Я вкотре прошу вас подорослішати; $A$ вас я прошу згадати Божу заповідь про любов до ближнього). Роз'яснення щодо захисту населення, висловлене в такий спосіб, не сприймається як нав'язані вказівки. Президент щиро вважає своїм обов'язком надати інформативну допомогу громадянам у питанні запобігання поширенню COVID-19.

Початок карантину став неочікуваною подією для українців, які працювали чи відпочивали за межами країни. Тож логічно, що для держави, яка дбає про своїх громадян, їхнє повернення додому має бути справою честі. До того ж у світових засобах масової інформації можна було щоденно чути, як США, Німеччина чи Франція за допомоги посольств і дипломатів організовують виїзд свої громадян додому, особливо з Китаю.

Президент України звертає увагу на цю проблему. У його виступах можемо простежити різні аспекти іiі розгортання. За три доби до закриття кордонів він попереджає: За иеей час ви повинні повернутися додому, де присудкове слово повинні має значення обов'язку для громадян, так складається враження, що держава перекладає цю проблему на них самих. Визначаючи це завдання, В. Зеленський уперше використовує слово обсервація (Всі, хто повернуться, будуть піддані медичній перевіриі. У разі виявлення ознак захворювання - направлені в обсервацію), яке викликає напругу в суспільстві. Можна пригадати ганебний факт, коли 20 лютого мешканці селища Нові Санжари, протестуючи проти розміщення на ізоляцію евакуйованих із Китаю, перекрили дорогу та вступили в сутичку з поліцією.

Глава держави звітує про моніторинг усіх можливих варіантів надання допомоги співгромадянам за кордоном. 17 березня більша частина звернення сприймається як докладна інструкція, де запропоновані різні шляхи для цього (співпраця з туроператорами, реєстрація в системі ДРУГ, зв'язок з МЗС, спецрейси, хабові точки). Президент віддає перевагу дієсловам у наказовому способі (зареєструйтесь, повідомте, надайте, зверніться). Оцінюємо цей мовленнєвий хід як позитивний. Першопричина невиконання наказу це відсутність мотивації, а зараз вона є очевидною - життя та безпека самих людей. Президент дає зрозумілі вказівки (наприклад: контакти ви знайдете на офіиійних сторінках відповідних установ або на сайті МЗС. Розділ: Посольства та консульства. Підрозділ: Дипломатичні установи). Переконує, що всі державні органи дбають про співгромадян, використовуючи займенники ми, нами, наші (ми обов'язково вас витягнемо). Серед іншого артикулюється кількість евакуйованих (Вчора 125 рейсів повернули додому 23 тисячі україниів. Сьогодні-50 рейсів і 10 тисяч украӥнців. На завтра заплановано ще 40 рейсів) та реальні кроки, здійснені державними органами.

Показово, що В. Зеленський звертається до громадянської самосвідомості. 26 березня він дає зрозуміти, що політика держави стає жорсткішою, це складний, проте вимушений крок: $M u$ опинились перед важким вибором між громадянами, які щее за кордоном, та безпекою сорока мільйонів громадян всередині краӥни. Президент підкреслює: держава піклується про всіх, але безпека всіх залежить від кожного. До 27 квітня риторика не змінюється, навпаки, він анонсує обов'язкові умови для повернення (Bci пасажири, які повернуться в Украӥну, будуть розподілені на дві групи. Перша $-<\ldots>$ зможе пройти обов'язкову самоізолячію <...> Інша частина громадян <..> пройдуть обсервачію в $<\ldots>$ підготовлених державою локаціях). У цих координатах відносин із нацією Президент визнає, що COVID-19 спричиняє мобілізацію іншої форми контакту між усіма їі членами. Люди, які в житті не взаємодіють між собою, усе одно взаємопов'язані, але лише доти, доки цей процес не загрожує їхньому життю. I тоді всі, хто не дотримується правил співіснування, спільнотою відкидаються. Нація дбає про свою безпеку в умовах пандемії та навіть готова відмовитися від тих, хто не виконує іiї правила. 
Соціальне завдання "вразливі групи населення та захист здоров'я і життя” містить один цікавий аспект - це поради Президента, що робити вдома, щоб дотримуватися карантину. Вони нагадують пропозиції дорослого дітям, коли їм нудно та вони не знають як себе розважити. Українці вперше чули від Президента, що їм читати, що подивитися, чим зайнятися та навіть як спілкуватися. Можна по-різному оцінювати роман “Вцілілий” Чака Поланіка чи французький фільм “Один плюс один”, беззаперечно визнати “Музей покинутих секретів” Оксани Забужко чи обрати посилання, за яким є електронні книжки, але заклик Збагачуємось духовно, залишаймося вдома i будьмо здорові, дорогі україниі! сприймаємо позитивно.

Ці пропозиції знову повертають усіх до питання про “здоров'я”. В. Зеленський називає свої поради традиційними (I традиційна порада, чим зайняти себе на карантині), пропонує то згадати про фізичну форму, то відвідати віртуальні тури украӥнськими музеями чи опанувати онлайн-можливості та навчити иьього своїх батьків, дідусів та бабусь, то всією краӥною "прокачати" навички та знання іноземних мов. Українці піддаються такому собі “карантинному окультурюванню”, що орієнтоване не так на їхнє благо, як на зручніші обставини для держави. Важко сказати, чи були ці послання результативними. Президент говорить, для прикладу, і про “особисте": Знаєте, сьогодні я подзвонив своій мамі. Всі изі дні я прому ї̈ залишатися вдома. I всі иі дні вона не дуже слухається. Це психологічний прийом, що дає змогу мати прихильність аудиторії, розвивати довірливі стосунки. Згадка про маму актуалізує важливі для українців смисли. Адже мати - це один із найбільш значущих образів для української культури. Як материнська любов береже життя дитини, дає їй любов і безпеку, так і любов дітей до матері повинна зберегти іiі. До цього аспекту апелює Президент, закликаючи турбуватися “як він” про рідних людей.

Ще одна сторона цієї кризової ситуації - заклик поговорити з батьками, друзями, дружиною чи чоловіком, дітьми ( $\mathrm{Mu}$ всі хотіли подзвонити батькам. Не на секундочку, а хоча б на годину. Ми хотіли подзвонити друзям, яких не чули майже 10 років, бо постійно робота, робота, робота). В. Зеленський акцентує на контактах із людьми, з якими кожен із нас має тісний особистий зв'язок, але переважно не має часу для спілкування. Він і сам визнає це своєю проблемою, застосовуючи займенник ми. Президент обирає хорошу позицію: ми обділяємо свою увагою найважливіших у житті людей, тож під час карантину це можна виправити. Щоправда, у шаленому ритмі життя багато хто втратив навички спілкуватися та чути один одного. В. Зеленський наводить яскраві приклади 3 життя: Поговорити зі своєю дружиною. Не "Привіт, дякую за вечерю, иілую, добраніч”. А поговорити. Згадати всі приємні миті, подорожі, перше побачення й заново закохатися одне в одного. Поговорити з власними дітьми. Не "Угу, добре. Перехочеш. Чому не робиш уроки...” А поговорити. Зрозуміти їхні захоплення, хобі, мрії, страхи. Він звертається до символічного моделювання життєвих фактів, що поряд із раціональнологічними побудовами інших соціальних завдань створюють буттєву цінність його виступів.

\section{2. Соціальне завдання "Робота лікарів $і$ медичне забезпечення"}

По-перше, В. Зеленський дякує за роботу українським медикам, які залучені до протидії коронавірусу. Його висловлення мають семантично складну структуру 3 позитивною оцінкою роботи лікарів, виявом емоції захоплення, але обтяжені занепокоєнням, співчуттям, закликами, проханням. Тому цю соціальну підтему сприймаємо як емотивно-оцінну та раціональну. Застосовуються різні типи висловлювань із семантикою подяки: пряма, емоційна подяка, мотивована, реалізована вербально та невербально (міміка, жести). Ці типи не ізольовані, вони взаємодіють, пов'язуючи різні кваліфікаційні параметри. Особливістю подання $є$ поєднання офіційних та особистісно значущих форм. Президент застосовує жанр не в ситуації урочистих подій, тому першорядною $\epsilon$ неофіційність, людська вдячність, але спілкування підпорядковане правилам політичного дискурсу.

Структура інтенцій вираження подяки містить важливі, але не однозначно значущі компоненти, що перетинаються. Фіксуємо дотримання Президентом етикетних норм мовлення, його емоційний стан, бажання впливати на поведінку українців та раціональну оцінку ситуації з COVID19. Проте не вбачаємо прагнення створювати чи підтримувати власний імідж, він не намагається дякувати лікарям, щоб “не бути в боргу”. В. Зеленський акцентується на заслугах людей, які взяли на себе відповідальність за чуже життя в ситуації розвитку складного захворювання та в умовах неготовності медичної системи до такого виклику. Тому на ментальному рівні підтема містить сигнали, які підкреслюють: на 
самовіддану роботу лікарів суспільство відповідає добрими словами; ми знаємо, що вони поступаються власними інтересами, здоров'ям, а держава та громадяни це високо цінують. Така інформація виокремлюється в лінгвостилістичній системі промов.

Мовні засоби для висловлення подяки не $є$ різноманітними, головно фіксуємо слова: спасибі, дякую, подяка, вдячні, вдячний, основне слово дякую / дякуємо, до яких можуть бути додані слова дуже, щиро (А щуе я хочу вкотре подякувати нашим українським медикам; Я щииро дякую кожному українському медику; I за все це я вкотре кажу вам: "Дякую!"; Дякуємо за те, шзо ви є!). Президент часто говорить від себе (Я також хочу подякувати кожному украӥнському лікарю), називає їхню роботу самовідданою, акцентує на їхній неймовірній витримиі, мужності, говорить про вірність клятві Гіппократа.

Символічним елементом стає згадка про військові дії на сході України (Так само як наші військові на передовій, ви захищаєте життя мільйонів украӥнців) та “кіборгів" - захисників Донецького аеропорту, які 242 дні відстоювали українську землю (Сьогодні кожен украӥнський лікар є “кіборгом", який стоїть на захисті здоров'я всісї начіi). Для нації лікарі стали супергероями (Сьогодні ви - наші супергерої).

Подяка не обмежується словами, бо незабезпечені та незахищені лікарі - це соціальна проблема, тому Президент наголошує: Ми зробимо все, щзоб вони були максимально захищені та заохочені, обіцяє: Буде збільшено виплати лікарям, які протидіють коронавірусу. Сьогодні украӥнські медики мужньо ведуть війну за життя та здоров'я украӥниів. А отже - ̈̈хні виплати мають бути на рівні бійців на передовій. В. Зеленський поєднує подяку із закликом: Давайте не допустимо ситуащії, коли вони будуть падати на роботі від перевтоми. Чи будуть змушені обирати, кого $з$ пацієнтів їм лікувати. Допоможіть свойй краӥні - залишайтеся вдома. Така мотивувальна кризова подяка є покажчиком високого ступеня усвідомленості цього соціального завдання.

\section{3. Соціальне завдання "Відповідальність державних органів влади”}

Найбільше уваги у своїх промовах Президент приділяє роботі Верховної Ради. Це законодавчий орган, але під час карантину її законотворчість, по- перше, була обмеженою, по-друге, підвищився рівень відповідальності, адже треба ухвалювати закони, що запобігають поширенню COVID-19. Президент знаходиться у двоякій ситуації: він має більшість депутатів своєї партії у Верховній Раді, але знає про невдоволення українців ії роботою. Тож комбінує різні мовні тактики: критика, вказівка, попередження, наказ, порада, шантаж, подяка.

В. Зеленський маніпулює задля тиску на депутатів. Наприклад, 16 березня лише в одному реченні він звертає увагу майже на всі аспекти життя України (а не лише COVID-19!), тому складається враження, що Президент хоче розв'язати всі проблеми “під гаслом коронавірусу” (Зараз <...> парламент України має ухвалювати життєво важливі для економіки закони, впроваджувати податкову, земельну, трудову реформи, призначити міністрів економіки та енергетики, Генерального прокурора Украӥни). Шантаж реалізовано у формі наказу (У такі часи всі народні депутати мають усвідомити відповідальність) із поясненням наслідків невиконання: У такі часи ви блокуєте не трибуну - ви блокуєте життя України. Без них економічна кома. Ще приклад тиску на депутатів Верховної Ради: Перший (шлях) - ие ухвалення двох життєво важливих законів. Після чого ми одержимо підтримку від наших міжнародних фінансових партнерів < .. > Інакше - другий шлях. Це - провал циих законів. Після - занепад економіки й навіть загроза дефолту. Фіксуємо й попередження: Завтра народ України чітко побачить, чи готові ви захищати його інтереси. Президент висловлює надію на взаєморозуміння 3 Верховною Радою. Але емоційний невербальний “сигнал” свідчить про невдоволення роботою депутатів (рис. 3).

Заохоченням для депутатів є поодинокі подяки (Окрема подяка Верховній Раді, яка не пішла на карантин; Я дякую кожному нашому народному депутату) та похвала (ви ухвалили багатостраждальний “банківський закон”. Ваше рішення стало зеленим світлом для отримання Украӥною важливої фінансової підтримки). Президент намагається демонструвати командну роботу з депутатами, оскільки криза може підірвати не лише економіку краӥни, але й суттєво вплинути на рейтинг В. Зеленського та nартї̈ “Слуга народу”.

Звертаючись до інших державних органів, В. Зеленський наполягає на ухваленні урядом низки важливих рішень, зокрема, не відключати 
електроенергію для населення за борги. Говорить про доставку ліків і їжі незахищеним верствам населення; дає завдання НБУ, Мінфіну та Мінекономіки розрахувати програму кредитних канікул для бізнесу та виплатити допомогу людям, які були скорочені через карантин. Він акцентує, що розуміс потреби всіх регіонів i разом із Кабінетом Міністрів України робить усе, щоб їх забезпечити.

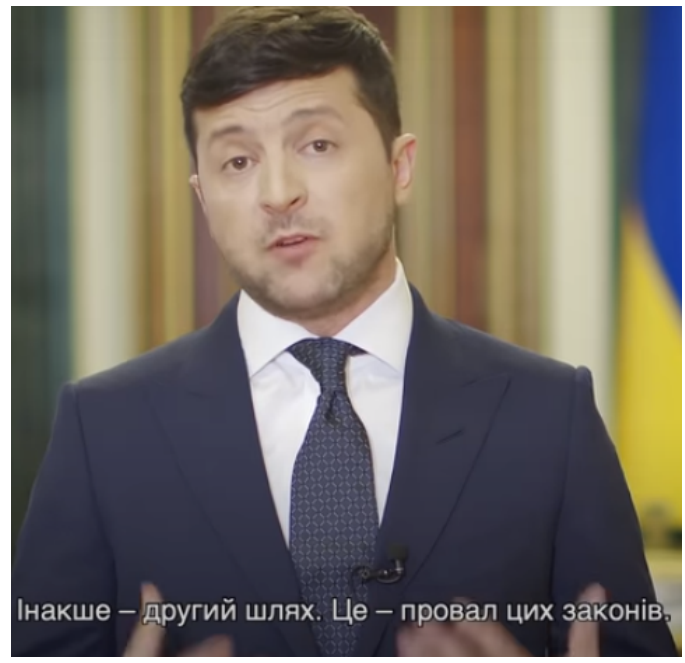

Рисунок 3 Емоційний “сигнал” про невдоволення роботою депутатів Верховної Ради

\section{4. Соціальне завдання "Гуманітарна допомога"}

Це надзвичайно важливе соціальне питання. 3 розповсюдженням вірусу людство усвідомило, що хвороба загрожує всім, діяти треба спільно, заходи окремих країн не результативні. Але економічно стабільні країни мають більше шансів вижити. Міжнародні організації, окремі держави прийшли на допомогу країнам, які мали менше шансів захистити своїх громадян. Неприємно чути, що Україна перед пандемією виявилася беззахисною та ми змушені чекати на допомогу. Президент розуміє нашу слабкість (немає тестів, засобів захисту, ліків тощо), тому у виступах подає інформацію про гуманітарну допомогу лише у площині фактично реалізованих домовленостей. Вперше підтема звучить 13 березня (Проводяться переговори з міжнародними партнерами щзодо надання гуманітарної допомоги) - і це лише повідомлення, оскільки результативність перемовин не зрозуміла.

$\begin{array}{llll}\text { Тільки за тиждень } & \text { В. Зеленський знову }\end{array}$ звертається до цієї теми. Особливі мовні засоби та ритміко-інтонаційне навантаження речень посилює та інтенсифікує інформування. Початкові фрази починаються прислівниками часу сьогодні, вчора, завтра, вночі (Сьогодні вночі у "Борисполі" приземлився наш перший вантажний літак із Китаю), чим наголошена реальність подій, успішність міжнародної допомоги. Поступово варіант уведення підтеми в текст змінюється. Президент говорить про тижневі вантажі, про традиційне прибуття або лише констатує, що прибув вантаж, прибули тести, доставлено вантаж або чекаємо на прибуття, де головно використано дієслова минулого часу. Він ніби звітує про гуманітарну допомогу, деталізуючи іiі кількісно (Це кілька десятків тисяч респіраторів, стільки ж костюмів захисту, 300 тисяч експрестестів, а також 40 тисяч пар захисних окулярів; <..> вже прибули в Украӥну 100 тисяч тестів ПЛР; Наша мета - найближчим часом доставити в Україну 50 мільйонів масок; Літак доставив 300 тисяч спеціальних респіраторів та 35 тисяч захисних костюмів для лікарів, військових $i$ полічейських. Також на борту - два мільйони масок; Також із Женеви доставлено гуманітарний вантаж від Міжнародного комітету Червоного Хреста. Дякуємо їм за иее!). Гуманітарна допомога - це вияв солідарності, підтримка. Тож логічно, що питання про гуманітарну допомогу та іiі справедливий розподіл між регіонами країни супроводжується висловленням прямої емоційної та мотивованої подяки. Президент говорить і про зміни до законодавства щодо кримінальної відповідальності за незаконний експорт товарів медичного призначення в період коронавірусу. Цю тезу можна сприймати у плані захисту національних інтересів.

\section{5. Соціальне завдання "Економіка"}

Президент під час карантину не міг звертатися до народу без озвучування фінансовоекономічного питання. Щоправда, ні громадяни, ні він сам тоді ще не усвідомлювали, наскільки коронавірус вплине на економіку країни, хоча й розуміли: магазини, ресторани, ринки чи кінотеатри не платитимуть податки, не буде фінансових надходжень від транспортної сфери, 3'являться нові вимоги до міжнародних контактів тощо. Лише за два місяці у травні В. Зеленський обережно озвучує це питання та говорить: Так, $\epsilon$ негативний вплив карантину на економіку. Втрати від нього - болючі, проте оточує цей висновок питанням про “здоров'я людей” (Але потенційні втрати від високої захворюваності та смертності - катастрофічні. Згідно 3 дослідженнями, повне скасування карантину матиме шокуючі наслідки). Звернімо увагу: вплив 
карантину на економіку країни названо негативним, а втрати від вірусу катастрофічними, тобто трагічними, руйнівними, або наслідки будуть шокуючі. Таке зіставлення та вибір слів приголомшує, за ним українці відчувають посилання - “ми бідні, але живі”, а вірус - наш спільний “ворог”. Формується суспільна думка, що криза посилить не лише економічні проблеми, більше відчуватиметься незахищеність; нерівність із сильними країнами світу стане ще відчутнішою. Тому логічно сприймається риторика про перемовини з МВФ та іншими міжнародними партнерами щзодо надання фінансової підтримки для подолання наслідків коронавірусу.

У виступі 18 березня категорично звучить заборона банкам нараховувати штрафи, підвищені відсотки за споживчими кредитами. Ця тактика реалізується експліцитно, грунтована на авторитетній позиції Президента. Декларується фінансова підтримка бізнесу ( $Я$ вітаю рішення НБУ знизити облікову ставку до восьми відсотків. <..> уряд та НБУ мають презентувати дві важливі програми. Перша - це іпотека для населення за ставкою близько 10\%. Друга - ие кредити малому бізнесу за низькою ставкою для виплати заробітних плат своїм працівникам), хоча конструкції рішення знизити чи мають презентувати програми знижують рівень довіри до обіцянок, сприймаються через призму ставлення до всіх тих намірів і планів, які президенти чи уряди декларують, але не виконують. Корумпованість, неефективність роботи деяких державних інститутів, непрозорість у використанні ресурсів, невисокий рівень економічного розвитку - проблеми, що вплинули на рівень політичної толерантності в питанні COVID-19: недовіра до політичних інститутів посткомуністичної країни стає на заваді навіть ефективній боротьбі з коронавірусом.

Заявлена також фінансова підтримка населення. Сьогодні можемо констатувати, що ці обіцянки загалом були виконані, проте у квітні обрані мовленнєві засоби ускладнювали сприйняття інформації. Форма майбутнього часу дієслів (буде проведено індексацію пенсій), присудки 3 модальними компонентами (мають одержати доплату в розмірі 1000 гривень; зможете отримати допомогу на дитину віком до десяти років; понад 300 тисяч родин підприємиів зможуть отримати допомогу) у семантичному аспекті не посилювали ступінь упевненості в цих фактах. Тож неоднозначність суспільної довіри до ефективності функціонування фінансово- економічної системи країни ставить перед Президентом складне завдання, яке він розв'язує стандартно. Це констатація факту погіршення економічної ситуації під час карантину (сприймається всіма 3 розумінням об'єктивної причини), обіцянки про допомогу міжнародних партнерів (українці звикли до таких заяв і в позакарантинний час) та зобов'язання перед певними верствами населення (також заявлено не вперше). Суспільне очікування певних рішень від влади не дає змогу Президенту позбавити уваги економічне питання. Водночас він не має впевненості в реалізації якихось нових програм, тому не акцентує на цьому.

\section{4. ВИСНОВКИ}

- COVID-19 став рушійною силою для суттєвих змін у риторичних інструментах, яким користується Президент України у своїх зверненнях. Пандемія поставила перед лідером країни завдання не лише пояснити ситуацію під час національної та міжнародної кризи, але й знайти підтримку, розуміння та позитивну реакцію на заходи, які здійснюють державні органи. Говорячи про коронавірус, він застосовує різні риторичні прийоми задля формування суспільно корисної реакції на пандемію загалом і на процеси, які неминуче іiі супроводжують. Особливі мовностилістичні засоби застосовано для того, щоб побудувати продуктивний діалог між Президентом і народом.

- Вipус зробив відчутнішими соціальні проблеми та помітнішими соціальні завдання, які можуть забезпечити функціонування країни в умовах кризи. Президент не міг уникати обговорення питання охорони здоров'я, економічної кризи чи політичних змін, оскільки спрямованість його звернень повинна вплинути на реакцію українців на пандемію. Ми виявили у 19 зверненнях В. Зеленського 5 найбільш важливих соціальних завдань.

- Національне спрямування риторики Президента щодо корона-кризи стало чіткою реакцією влади на етапі спалаху пандемії. Тому в тезах, які орієнтовані на громадян, Президент поєднує раціональні висловлення 3 емоційнонапруженим монологом, патетикою, ритмізованим синтаксисом, повторами, перемикає стильові коди, послаблюючи напругу, інколи знижуючи запал мови до повсякденного дружнього коментаря.

• В. Зеленський, говорячи про функціонування держави, демонструє, що він відповідальний лідер 
та у кризовий час буде діяти впевнено, чітко, навіть жорстко. Президент реагує в авторитарному стилі, піддає тиску i політичних друзів, i опонентів. Він наголошує: Україна не може покладатися на загальноєвропейську координацію, але акцентує на допомозі від МВФ, ВОO3, на спілкуванні з країнами Європи та Азії. Основним маркером стає “вірус-ворог”, якого треба “знищити”. Іншу риторику складно уявити. Президент проявляє впевненість і співчуття, вдається до переконань, апелює до національних цінностей i символів, трансформуючи їх $\mathrm{y}$ радикальну надію - перемогу над COVID-19.

У перспективі можлива індексація кризової риторики В. Зеленського через лінзу формування суспільної довіри до його слів та ефективної реакції.

\section{REFERENCES}

[1] P.L. Dunmire, Political Discourse Analysis: Exploring the Language of Politics and the Politics of Language, Language and Linguistics Compass 6(11) (2012) 735-751. DOI: https://doi.org/10.1002/lnc3.365

[2] M. Sharififar, E. Rahimi, Critical Discourse Analysis of Political Speeches: A Case Study of Obama's and Rouhani's Speeches at UN, Theory and Practice in Language Studies 5(2) (2015) 343-349.

DOI: http://doi.org/10.17507/tpls.0502.14

[3] F. Fischer, H. Gottweis (Eds.), The argumentative turn revisited: Public policy as communicative practice, Duke University Press, Durham, NC, 2012.

[4] N.V. Kondratenko, Ukrayins'kyy politychnyy dyskurs: tekstualizatsiya real'nosti [Ukrainian political discourse: textualization of reality], Chornomor"ya, Odesa, 2007.

[5] A. Kravets', Politychna antropolohiya [Political anthropology], Dnipropetrovs'k, 2012.

[6] L.P. Nagornaya, Politychna mova i movna polityka: diapazon mozhlyvostey politychnoyi linhvistyky [Political language and language policy: the range of possibilities of political linguistics], Svitoglyad, Kyiv, 2005.

[7] Z. Iqbal, M.Z. Aslam, T. Aslam, R. Ashraf, M. Kashif, H. Nasir, Persuasive power concerning COVID-19 employed by Premier Imran Khan: A socio-political discourse analysis,
Register Journal 13(1) (2020) 208-230. DOI: https://doi.org/10.18326/rgt.v13i1.208-230

[8] M. Kranert et al. COVID-19: The World and the Words. Linguistic means and discursive constructions, in: DicourseNet, Special Issue: Discourse Studies Essays on the Corona-Crisis, no. 2/9, August 2020. https://discourseanalysis.net/sites/default/files/2 020-09/Kranert_et-al_2020_DNCWPS_2-9.pdf

[9] A. Sabah, J. Al-Khayyat, M. Maha, A. AlKhayyat, Covid-19 and its Influence on the Political Speeches: A Discourse Analysis Study of the Use of Pronouns in Selected Presidential Speeches as a Model to Training EFL Postgraduate Students, Journal of University of Shanghai for Science and Technology 22(10) (2020) 1627-1635.

[10] S. Dada, H. Ashworth, M.J. Bewa, R. Dhatt, Words Matter: Political and gender analysis of speeches made by heads of government during the COVID-19 pandemic, in: medRxiv, Cold Spring Harbor Laboratory Press, September 2020.

DOI: https://doi.org/10.1101/2020.09.10.20187427

[11] T.A. van Dijk, What is Political Discourse Analysis? Universiteit van Amsterdam, 1995. http://www.discourses.org/download/articles/

[12] N. Fairclough, Critical Discourse Analysis: The Critical Study of Language, 2nd ed, Longman, Harlow, 2010.

[13] President of Ukraine: Speeches, 2020. https://www.president.gov.ua/en/news/speeches.

[14] World Health Organization (WHO), Coronavirus disease (COVID-19) Pandemic, 2020. https://www.who.int/emergencies/diseases/novel -coronavirus-2019 on December 10, 2020. 